技術論文

\title{
電磁石を用いた粒状体ダンパー減衰力の設置角依存性の低減
}

\section{Reduction of Effect of Installation Angle of a Damper Utilizing a Particle Assemblage on Damping Force by Using Electric Magnets}

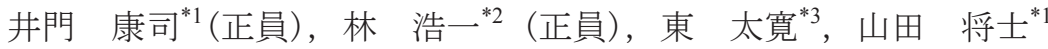

Yasushi IDO (Mem.), Kocihi HAYASHI (Mem.), Takahiro AZUMA, Masashi YAMADA

\begin{abstract}
Damping property of a damper utilizing a magnetic particle assemblage in the presence of magnetic field is investigated experimentally. The damping force depends on installation angle of the damper in the absence of magnetic field. In our study, one or two electromagnets are arranged near the edges of the damper case and we have found that effect of installation angle of the damper becomes small in the presence of magnetic field in this configuration. Applying magnetic field by two electromagnets arranged near the edge of the damper is useful method to suppress asymmetric damping property due to the gravitational force acting on the particles.
\end{abstract}

Keywords: electromagnet, magnetic particle, damper, particle assemblage, vibration, installation angle.

\section{1 緒言}

振動する物体に固定された容器に粒子あるいは粒 子群を入れ, 振動とともに発生する粒子と容器壁面と の衝突や摩擦を利用した粒状体衝撃ダンパーが提案さ れて, 多くの研究が行われている[1-3]。金属やプラス チックなどの粒子は固体であるが，その集合体である 粒状体は流体のような流動性を有することが知られて いる。この特性を利用した粒状体ダンパーが提案され ており $[4,5]$, 容器内にある粒子群の中をピストンが移 動する際に発生する摩擦や弾性反発力を利用するもの である。これらのダンパーは基本的に容器の一部が開 放されているものであるが，著者らはオイルダンパー の作動流体の代わりに粒状体を充填した構造を持つダ ンパー，すなわち閉空間内に粒状体を充填したダンパ 一について，強制変位を与えた場合の減衰力特性を実 験的に調べ，一般的なオイルダンパーや摩擦ダンパー とは異なる減衰力特性を有することを明らかにしてい る[6]。ダンパー内の粒状体が充填されている容器内に は空陌が存在する。そのため, 粒状体ダンパーは設置 角度によってその減衰力特性が変化することもわかっ ている[7]。すなおち, 水平に設置した場合にはピスト ンの移動方向に依らず減衰力が発生するが，傾斜角が ある場合, ピストンが上方に移動するときにはほとん 連絡先： 井門 康司, $\bar{\top} 466-8555$ 名古屋市昭和区御器所 町, 名古屋工業大学大学院工学研究科ながれ領域, e-mail: ido.yasushi@nitech.ac.jp
${ }^{* 1}$ 名古屋工業大学
*2 鳥羽商船高等専門学校
*3 トヨタ車体 (株)

ど減衰力が発生しない。このような減衰力が発生しな い状態を避けるため，著者らはバネを利用した設置角 依存性を低減する機構を提案した[8]。しかしながら， このようなバネ機構を利用した場合，設置角依存性は ほぼ無くなるものの, 粒状体ダンパーの減衰力の特徵 であった，漸硬型の特性もなくなり，単純な摩擦ダン パーに近い減衰力特性を示すようになる。さらにバネ 機構は機械的な可動部を新たに組み込むことになり， 耐久性の低下や故障の原因を増やすことにつながる。

一方，粒状体として鋼球などの磁性粒子を用い，ダ ンパー外周部を覆うように設置した電磁石によって磁 場を印加すると, 減衰力特性が変化して死点近傍での 減衰力が急増することが明らかとなっている[9]。これ は粒子が磁場勾配による磁気力を受けることや，磁気 的相互作用力によって粒子同士が引き合うことによっ て生じるものと考えられる。このような磁場印加に対 する粒子の挙動を利用することにより，磁場の印加方 法によっては前述の減衰力が設置角に依存する問題を 低減することができるものと期待される。

そこで本研究では，粒状体として磁性粒子である鋼 球を使用し，電磁石をダンパー端部の両側，あるいは 片側に設置して磁場を印加し，減衰力の設置角依存性 が低減できるかを実験的に明らかにする。

\section{2 実験装置および実験条件}

\section{1 粒状体ダンパー}

本実験では Fig. 1 に示すようなダンパーを用いた。 


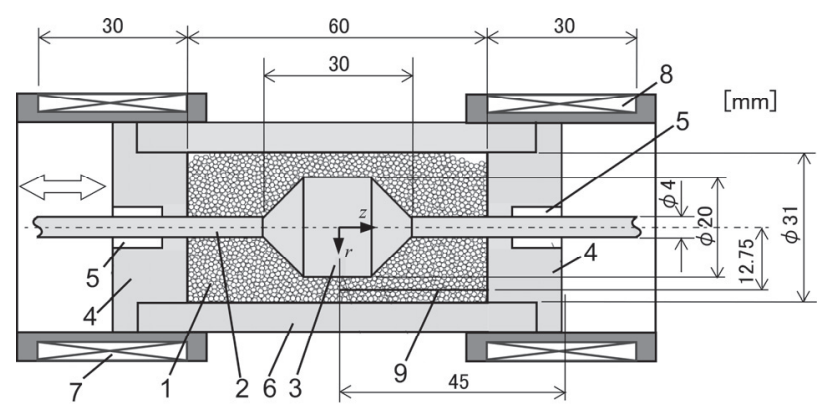

Fig. 1 Schematic of the damper utilizing a particle assemblage. 1: Particles, 2: Rod, 3: Piston, 4:End cover, 5: Bearing, 6: Cylinder, 7: Coil 1, 8: Coil 2, 9: Line for measuring magnetic flux density.

シリンダーとエンドカバーで囲まれた閉空間内に粒状 体が充填されており，その中をピストンがロッドと共 に動く構造となっている。ピストンは円柱の両端に $45^{\circ}$ のテーパーを設けた形状となっている。ロッドは ピストンの両端に取り付けられており, ピストンの位 置に依らず，ダンパー内容積は常に一定である。ロッ ドはリニアベアリングにより支持されており，しゅう 動部の摩擦抵抗は小さい。ダンパー内に充填される粒 状体として, 直径 $0.5 \mathrm{~mm}$ の鋼球（ベアリング鋼球, 材質 SUJ2, 等級 G500）を用い，エタノールで簡易的 に脱脂した状態でダンパーに充填した。

磁場を印加する電磁石として, ダンパーの両側また は片側のエンドカバー部にコイルを配置する。本実験 では Fig. 2 に示すように片側にコイルを配置した Case I と Case II, および両側にコイルを配置した Case III の 3 通りの配置について, 印加磁場下での減衰力測定 を行う。配置する位置は Fig. 1 に示している。コイル は直径 $0.8 \mathrm{~mm}$ のエナメル線を 414 回巻いたものであ る。Fig. 1 に示すようにコイルの端部とエンドカバー 内壁面が一致するようにコイルを設置する。座標軸と してロッド軸方向を $z$ 軸, それと直交する方向に $r$ 方 向を取る。このコイルに直流電流を流した場合に発生

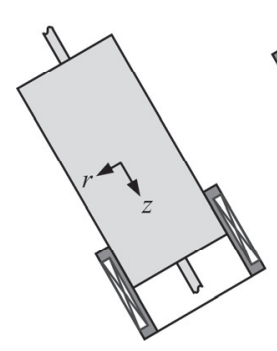

(a) Case I

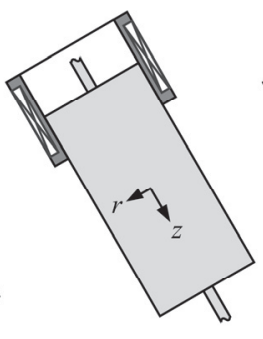

(b) Case II

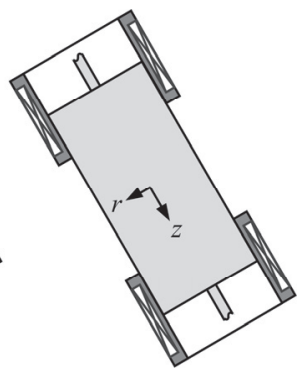

(c) Case III
Fig. 2 Arrangement of coils for applying magnetic field.
する磁束密度の $z$ 成分分布を Fig. 3 に示す。磁束密度 分布の測定位置はピストンとシリンダー内壁間の中央 位置であり, Fig. 1 に示している。Case III の場合, $-z$ 方向の分布は Fig. 3(b)の分布とほぼ対称である。

\section{2 実験装置および実験条件}

Fig. 4 に実験装置の概略図を示す。粒状体ダンパー の設置角は, 実験装置全体を傾斜させることで与えた。 モーター（オリエンタルモーター, BX6400S）の回転 をスライダー・クランク機構によって直線往復運動に 変換して動力源とし，正弦波状の強制変位を粒状体夕゙ ンパーに与える。強制変位の加振周波数はモーターコ ントローラにより任意に設定可能であり，振幅はす心゙ ての実験において $4 \mathrm{~mm}$ で固定している。強制変位を 与えた際の, 粒状体ダンパー内ピストンの変位はレー ザー変位計（キーエンス，センサーヘッド：LB-040, アンプユニット：LB-1000）を用い, 変位に伴い発生 する減衰力はロードセル（共和電業, LUX-A-1kN）を 用いてそれぞれ測定し，オシロスコープ（横河電気， DL1620）で記録した。以下の実験結果では，ロードセ ルに引つ張り力が作用する場合, 減衰力は正の值を取 るものとする。

実験条件として，粒状体ダンパーの加振周波数は

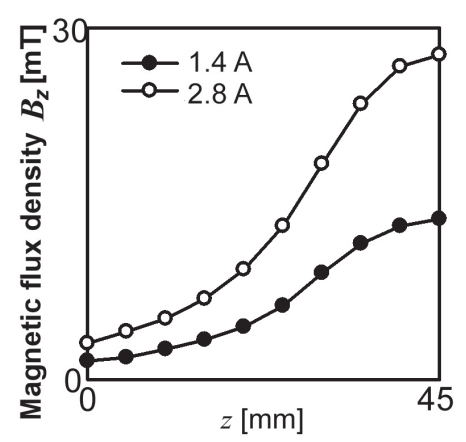

(a) One coil (Case I and Case II)

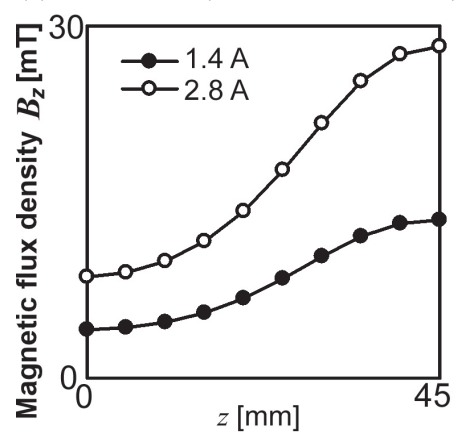

(b) Two coils (Case III)

Fig. 3 Distribution of $z$ component of magnetic flux density. (a) One coil and (b) two coils. 


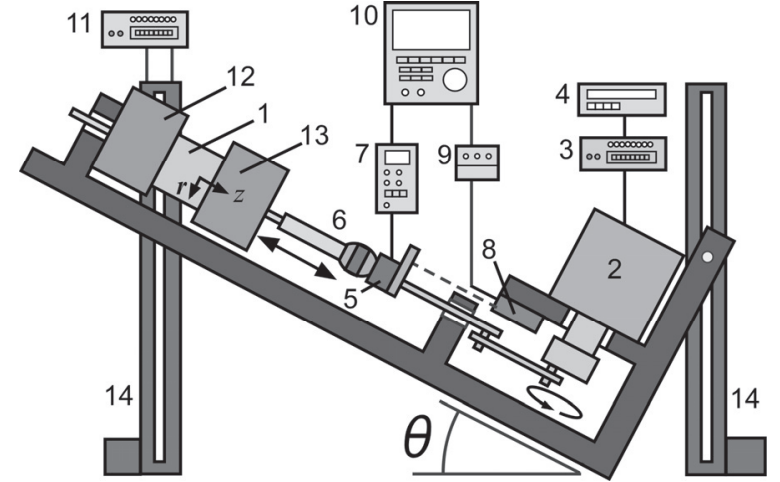

Fig. 4 Schematic of the experimental apparatus. 1: Damper, 2: Motor, 3: Motor driver, 4: Motor controller, 5: Load cell, 6: Ball joint, 7: Strain amplifier, 8: Displacement sensor, 9: Amplifier unit, 10: Oscilloscope, 11: DC power supply, 12: Coil1, 13: Coil 2, 14: Prop.

$1 \mathrm{~Hz} ３ \mathrm{~Hz}$ および $5 \mathrm{~Hz}$ とし，磁場を印加するためにコ イルに流す電流值として 0 A (無磁場)，1.4 A および $2.8 \mathrm{~A}$ とした。粒状体ダンパーに封入する粒状体の充填 率は，す心゙ての実験条件において 0.606 とし，ダンパ 一の設置角 $\theta$ として, 水平に設置した場合の $0^{\circ}, 30^{\circ}$ ， $60^{\circ}$ および $90^{\circ}$ について実験を行った。なお, 粒子径 および粒状体の充填率については，これまでの実験を 踏まえて粒子の流動性を確保でき, かつ最も安定した 減衰力が得られる条件とした。測定を開始する前に, ウォーミングアップとして, 磁場を印加せずに加振周 波数 $5 \mathrm{~Hz}$ で 20 分間加振した後に実験を行った。また, 磁場を印加した実験では，測定終了後に毎回消磁を行 つている。なお，測定された減衰力には，ダンパー摺 動部における摩擦力を含んでいるが，この摩擦による 抵抗力はダンパーが発生する減衰力に対して十分に小 さいため，無視している。

\section{3 実験結果および考察}

本研究では $1,3,5 \mathrm{~Hz}$ の各加振周波数で実験を行っ ているが，ここでは $3 \mathrm{~Hz}$ の結果について示す。他の加 振周波数の場合にも，結果は基本的に同様である。

\section{1 片側にコイルを配置した Case I の場合}

Fig. 5 に Case I の場合について減衰力と変位の関係 を示す。減衰力一変位曲線は, 時計回りが時間進行に 対応する。Fig. 5 より, 磁場を印加しない場合には, 設置角 0 度の場合を除いて，ピストンが重力の向きと は逆向きに移動するときに減衰力がほとんど発生して いない。ところが，ダンパー下側に設置した電磁石に

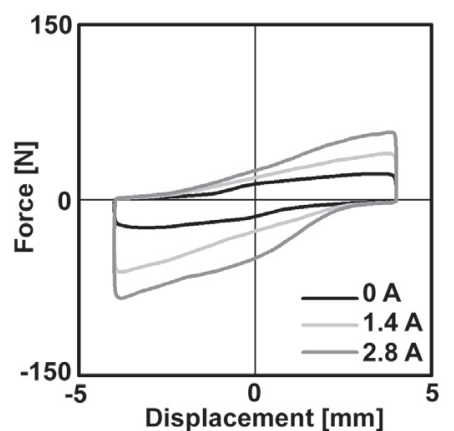

(a) 0 degree

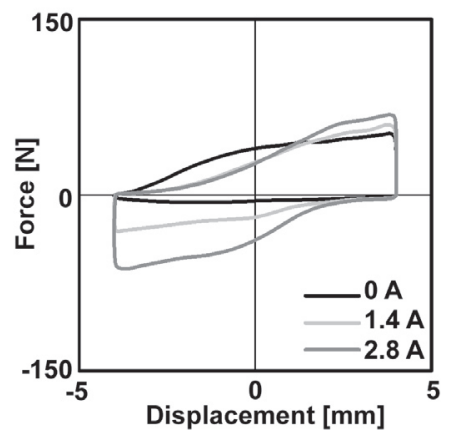

(b) 30 degree

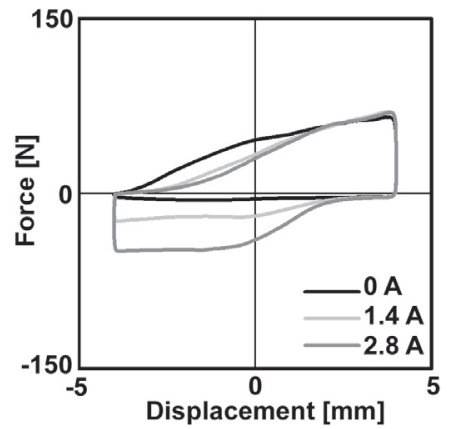

(c) 60 degree

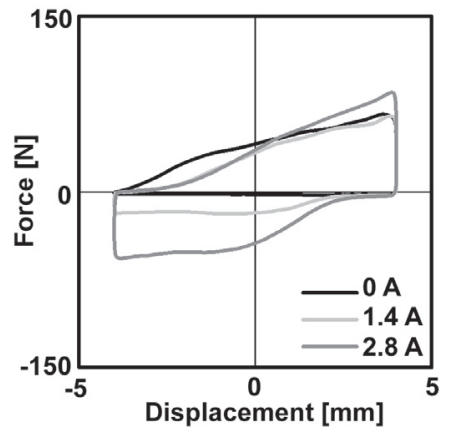

(d) 90 degree

Fig. 5 Damping force vs. displacement curves when one coil is arranged downside (Case I). The frequency is $3 \mathrm{~Hz}$.

よって磁場を印加すると，ピストンが重力の向きとは 逆の上方に移動する場合にも減衰力が発生しているこ とがわかる。印加磁場を大きくすると，この際に発生 する減衰力も大きくなり，減衰力特性のダンパー設置 
角への依存性は大きく低減されており，ピストンがど ちらの向きに移動しても減衰力が発生するようになる。 磁場が印加されるとダンパー内の磁性粒子には 2 種類 の磁気力が作用する。すなわち, 磁場印加によって個々 の磁性粒子が磁気モーメントを持ち, これによって生 じる粒子間に作用する磁気的相互作用力と磁場勾配に よって生じる磁気力である。下側に電磁石を配置して 磁場を印加した場合, Fig.6に示寸ように粒子に圧縮力 が作用しているものと考えられる。色が濃い方が強い 力が作用していることを示す。下側で磁場が印加され ると，エンドカバー近傍に粒子が引き寄せられる。ピ ストンが下向きに移動している場合には，ピストンよ り下側に引き寄せられた粒子があるため, 粒子からの 弾性反発力が大きくなるとともに, 摩擦力も大きくな る。一方, ピストンが上方に移動する場合には, 磁気 カによってピストン変位後の空隙に粒子が移動しにく くなるため, Fig. 6(b)に示すように移動するピストン後 方に生じた空陌が粒子ですぐには埋められず, オリフ イス部やその近傍で粒子の局所的なかさ密度が上昇し て流動性が低下寸る。そのため, ピストン進行方向側 に残存する粒子が多くなり, より大きな弾性反発力が 発生するとともにオリフィス部を通過する粒子による 摩擦力も大きくなり, 減衰力が増加するものと考えら

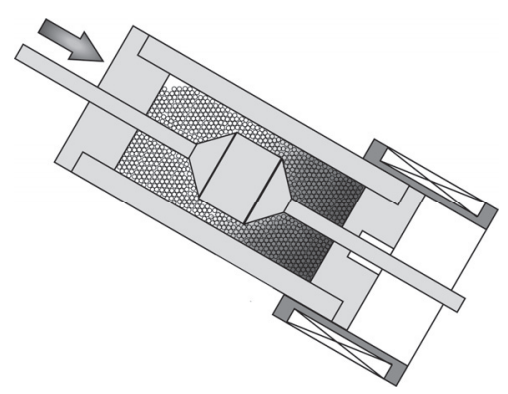

(a)

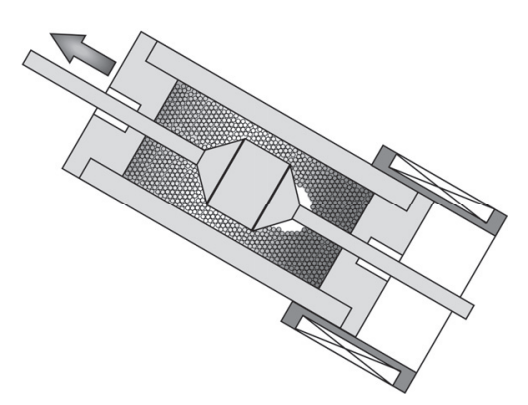

(b)

Fig. 6 Schematic of the distribution of compression force acting on the particles when the piston moves toward (a) downside and (b) upside (Case I).
れる。Case I の場合にダンパーが水平に設置されてい るにもかかわらず，磁場を印加するとピストンの進行 方向によって減衰力の出方に差が出るのは同じ理由に よるものと考えられる。

\section{2 片側にコイルを配置した Case II の場合}

次に 1 個のコイルを上側に配置した Case II の場合 について, 減衰力一変位曲線を Fig. 7 に示す。Fig. 7 よ り, 電磁石を上側に配置して磁場を印加した場合にも, ダンパー設置角依存性が低減されているが, Case I の 場合よりもその効果は小さい。Case II の場合, Fig. 8 に示すように粒子に圧縮力が作用しているものと考え られる。ピストン下降時には重力によって下部に集ま っている粒子を圧縮することで弾性反発力と摩擦力が 大きくなる。一方，ピストン上昇時には上部に設置さ れた電磁石で発生する磁場によって上側エンドカバー 近傍の粒子が上部に引き寄せられて重力による局所的 なかさ密度の低下が抑えられており，これらの粒子が ピストンによって移動・圧縮されるため, 弾性反発力 および摩擦力が大きくなると考えられる。この場合も, 印加磁場強度が強い方がその低減効果も大きい。

\section{3 両側にコイルを配置した Case III の場合}

Fig. 9 に 2 個のコイルをそれぞれ上側と下側のエン ドカバー近傍に配置した場合の, 減衰力一変位曲線を 示す。Fig. 9 より, 両側に電磁石を配置して磁場を印 加すると, 減衰力特性はほぼピストンの移動方向に依 存せず，ダンパー設置角依存性が大きく低減されてい ることがわかる。この場合, 内部の粒子に作用寸る圧 縮力は Fig. 10 のような分布になると考えられる。すな わち両側に電磁石が設置されているため, 両側のエン ドカバー近傍にある粒子はそれぞれのエンドカバー側 に引き寄せられる。ピストンが上昇する場合には先に 述べた Case I の場合と同様に，ピストンの上昇に伴う 粒子の上部への移動が阻害され，ピストン移動後に生 じる空隙を粒子がすぐには埋めることができない。そ のため, 上部の粒子の見掛けのかさ密度が上昇し, 弾 性反発力および摩擦力が大きくなり, 減衰力も大きく なると考えられる。

ここまでの結果より, 鋼球を用いた粒状体ダンパ 一のエンドカバー近傍に電磁石を配置して磁場を印 加することで, 粒状体ダンパー減衰力の設置角依存 性を低減できることが明らかとなった。本実験では, 電磁石で印加される磁場は Fig. 3 より最大約 $20 \mathrm{mT}$ 
程度である。したがって, 電磁石に替えて永久磁石 を同様に配置することでも, 設置角依存性の低減が 期待できる。特に本実験では 1 個の電磁石を下側に 配置した場合には, 設置角依存性低減効果はそれほ ど大きくはなかったが，より強い磁場を印加するこ

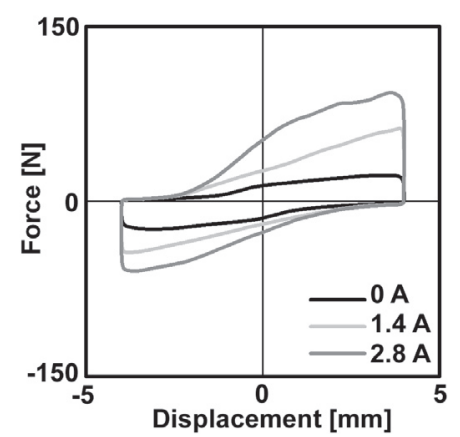

(a) 0 degree

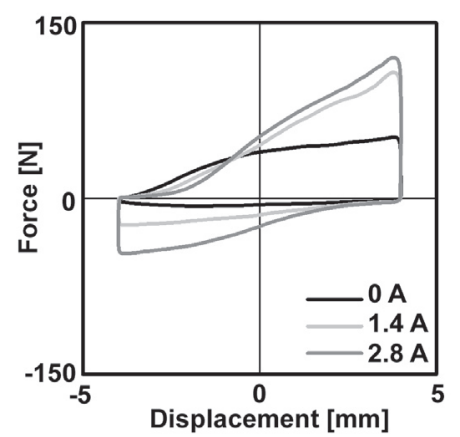

(b) 30 degree

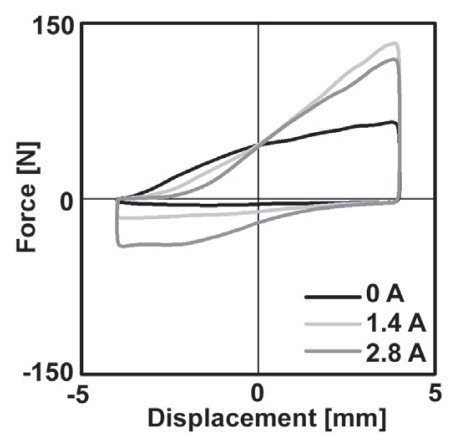

(c) 60 degree

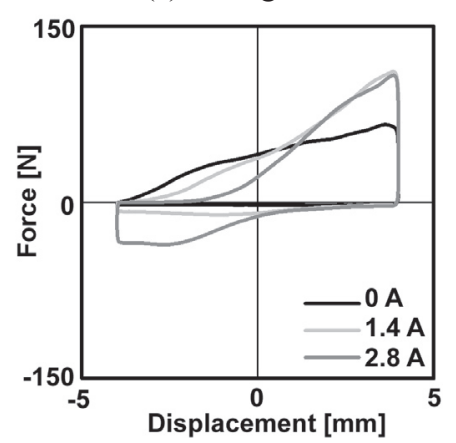

(d) 90 degree

Fig. 7 Damping force vs. displacement curves when one coil is arranged upside (Case II). The frequency is $3 \mathrm{~Hz}$.
とで十分な低減効果が得られる可能性がある。磁石 の配置場所についても検討が必要であり，これらに ついては今後, 実験等によって明らかにする。また, 磁場を印加した場合，ピストンが死点から中央に戻 り始めるときに減衰力があまり得られていない点に ついては，エンドキャップ位置やピストンサイズを 変更することによって減衰力を得られるようにする ことも可能である[10]。

\section{4 結言}

粒状体として磁性粒子を用い，電磁石をダンパーエ ッジ部両側または片側に配置して磁場を印加すること により, 粒状体ダンパー減衰力が設置角によって変化 する設置角依存性を低減できる。片側のみに電磁石を 配置する場合, 電磁石を下側に配置した方が上側に配 置した場合よりも設置角依存性が大きく低減される。 減衰力特性の設置角依存性が低減されたことにより, 粒状体ダンパーが使用可能な状況が大幅に拡大した。

本実験の結果より, 電磁石に替えて永久磁石を用い ることによって，簡便に減衰力特性の設置角依存性を 低減することができるものと期待される。

\section{謝辞}

本研究の一部は, 科学研究費補助金（23560259）な

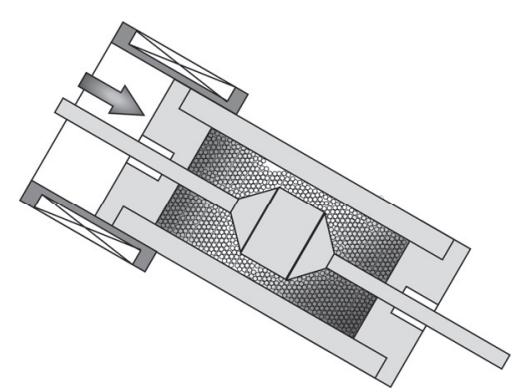

(a)

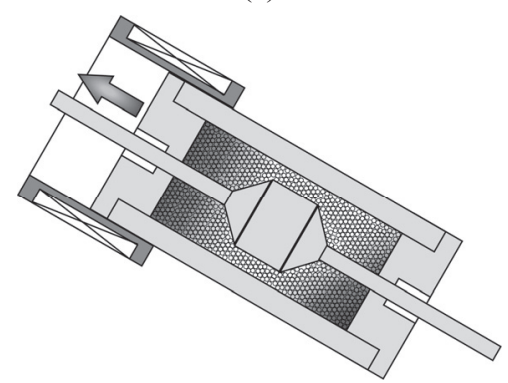

(b)

Fig. 8 Schematic of the distribution of compression force acting on the particles when the piston moves toward (a) downside and (b) upside (Case II). 


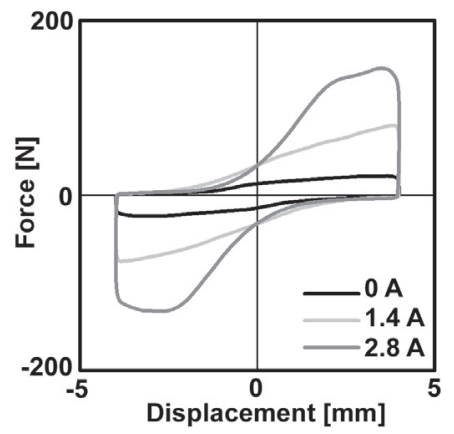

(a) 0 degree

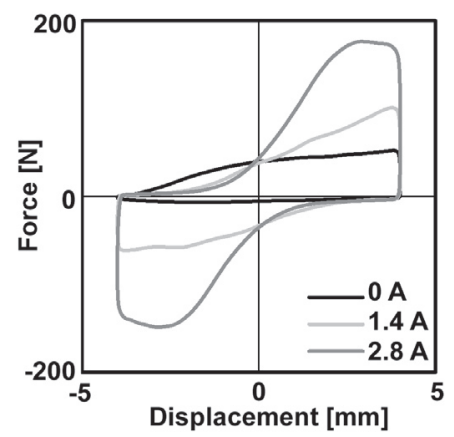

(b) 30 degree

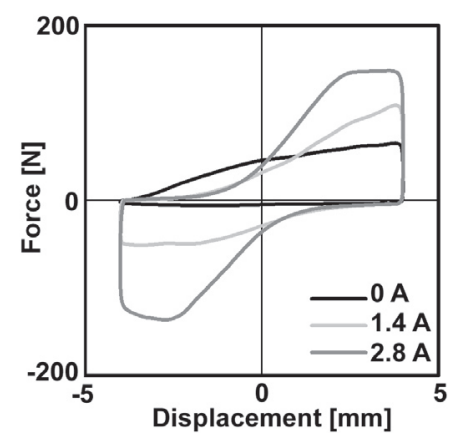

(c) 60 degree

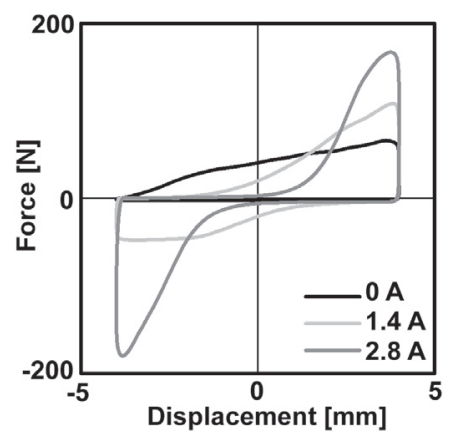

(d) 90 degree

Fig. 9 Damping force vs. displacement curves when two coils are arranged both sides of the damper (Case III). The frequency is $3 \mathrm{~Hz}$.

\section{らびに KYB 株式会社による援助によって行われた。} また実験遂行にあたり，協力をしていただいた名古屋 工業大学学部生の川本竜佑氏に感謝の意を表する。

(2014 年 1 月 30 日受付)

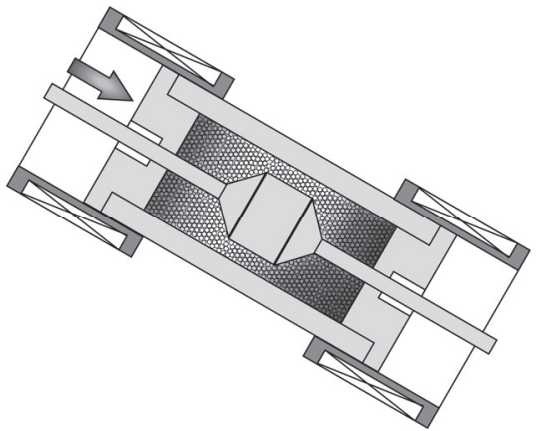

(a)

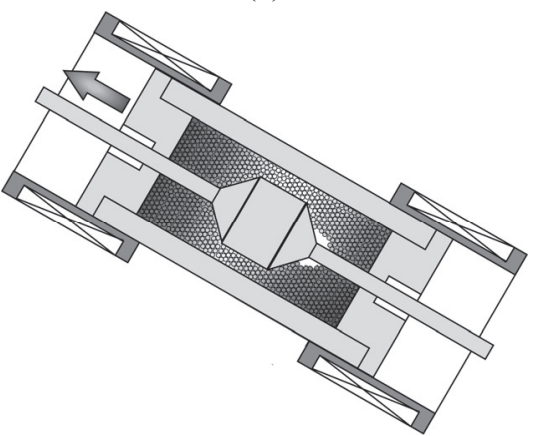

(b)

Fig. 10 Schematic of the distribution of compression force acting on the particles when the piston moves toward (a) downside and (b) upside (Case III).

\section{参考文献}

[1] H. V. Panossian, An overview of NOPD: a passive damping technique, Shock and Vibration, Vol. 1, pp.4-10, 1991.

[2] H. V. Panossian, Structural damping enhancement via non-obstructive particle damping technique, ASME Journal of Vibration and Acoustics, Vol. 114, pp.191-105, 1992.

[3] S. E. Olson, An analytical particle damping model, Journal of Sound and Vibration, Vol. 264, pp.1155-1166, 2003.

[4] X. M. Bai, B. Shah, L. M. Keer, Q. J. Wang and R. Q. Snurr, Particle dynamics simulations of a piston-based particle damper, Powder Technology, Vol.189, pp.115-125, 2009.

[5] 太田徹造, 防振装置, 特開平 8-219377.

[6] 林浩一，井門康司，粒状体の流動性を利用したダンパの 減衰特性, Vol. 10, No. 1, pp. 63-68, 2010.

[7] 伊藤匠, 林浩一, 井門康司, 粒状体ダンパー減衰力の設 置角依存性, 日本機械学会 2011 年度年次大会講演会講 演論文集，No.11-1, G100054, 2011.

[8] 林浩一, 伊藤匠, 井門康司, 設置角依存性のない粒状体 ダンパー機構, 日本実験力学会 2012 年度年次講演会講演 論文集，pp. 311-312, 2012.

[9] Y. Ido, K. Hayashi and T. Kawai, Damping Force of a Semiactive Damper Utilizing Magnetic Particles Under Applied Magnetic Field, International Journal of Applied Electromagnetics and Mechanics, Vol.39, pp. 535-540, 2012.

[10] 川合环真，清水智弘，林浩一，井門康司，鋼球を用いた 粒状体ダンパー減衰力の印加磁場依存性, 第 25 回電磁力 関連のダイナミクスシンポジウム講演論文集, pp.136-137, 2013. 